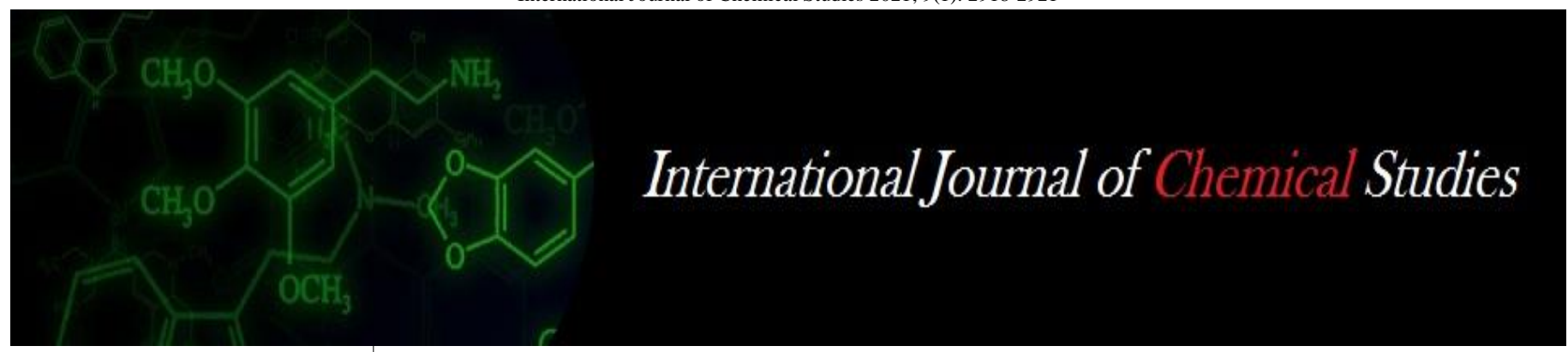

P-ISSN: 2349-8528

E-ISSN: 2321-4902

www.chemijournal.com

IJCS 2021; 9(1): 2918-2921

(C) 2021 IJCS

Received: 07-10-2020

Accepted: 18-11-2020

\section{SD Rathod}

PG Student, AICRP on Forage Crop and Utilization, Mahatma Phule Krishi Vidyapeeth,

Rahuri, Maharashtra, India

\section{GC Shinde}

Assistant Professor, Department of Agricultural Botany, AICRP on Forage Crop and Utilization, Mahatma Phule Krishi

Vidyapeeth, Rahuri,

Maharashtra, India

SD Shinde

SRA, Department of Agricultural Statistics, MPKV, Rahuri, Maharashtra, India
Corresponding Author: SD Rathod

PG Student, AICRP on Forage Crop and Utilization, Mahatma Phule Krishi Vidyapeeth, Rahuri, Maharashtra, India

\section{Genetic diversity studies in forage maize genotypes}

\section{SD Rathod, GC Shinde and SD Shinde}

DOI: https://doi.org/10.22271/chemi.2021.v9.i1ao.11672

\begin{abstract}
Fifty four genotypes of forage maize were evaluated at research farm of AICRP on Forage Crops and utilazation, M.P.K.V., Rahuri in a RBD design with two replications during the rabi, 2018-19. The observations were recorded on yield and yield contributing traits viz., days to 50\% tasseling, days to silking, plant height $(\mathrm{cm})$, number of leaves/tiller, number of internodes/tiller, leaf length $(\mathrm{cm})$, leaf breadth $(\mathrm{cm}), \mathrm{L} / \mathrm{S}$ ratio, stem girth $(\mathrm{cm})$, green forage yield $(\mathrm{kg} / \mathrm{plant})$, dry matter percentage and crude protein percentage. Based on genetic distance $\left(\mathrm{D}^{2}\right.$ value) fifty four genotypes were grouped into seven clusters indicating wider genetic diversity in the germplasm collections of maize from different geographical origin. Out of seven clusters formed, Cluster I was the largest with 38 genotypes, followed by cluster VI with 7 genotypes, followed by cluster IV with 5 genotypes. Cluster II, III, V, and VII were monogenotypic. The clustering pattern indicated the absence of relationship between genetic diversity and geographical origin of genotypes. The maximum intra cluster distance was observed for cluster IV $(D=7.71)$ followed by cluster $I(D=7.19)$, followed by cluster VI $(D=6.12)$. Whereas, the maximum inter cluster distance was observed between cluster IV and cluster VI $(\mathrm{D}=18.92)$ followed by cluster IV and cluster V ( $\mathrm{D}=16.68)$, while lowest divergence was noticed between cluster II and VI $(\mathrm{D}=7.77)$. On basis of inter cluster distances, cluster mean and per se performance and divergence class observed in the present study, the genotypes viz., 52095, 52217, 52336, 52483, 52507, 52623 and African tall were distinct and diverse and could be classified as promising genotypes. These genotypes may be used in crossing programme to achieve desired segregants in forage maize.
\end{abstract}

Keywords: $\mathrm{D}^{2}$, clusters, diversity, protein, forage yield

\section{Introduction}

Forage maize is quick growing, succulent, sweet palatable, high yielding, nutritious and free from toxicants and can be safely fed to animals at any stage of crop growth (Devi, 2002) ${ }^{[6]}$. It is utilized in the form of grains, green fodder, silage, Stover and pasturage. Green fodder provides adequate energy and proteins for growth of animals and milk production (Takawale et al., 2009) ${ }^{[21]}$. Corn is an important feed for animal and poultry with high net energy content and low fibre content.

Germplasm, which is a prerequisite for any breeding programme, serves as a valuable source material as it provides scope for building of genetic variability. Mahalanobis $\mathrm{D}^{2}$ analysis is very useful tool in studying the nature and cause of diversity prevalent in the available germplasm knowledge of genetic variability is very valuable in a planned breeding programme, since it helps in the choice of the best yield attributes either for selection or for hybridization.

\section{Material and Methods}

The field experiment was carried out at the AICRP on Forage Crops and Utilization, MPKV, Rahuri, during rabi 2018-19 to study the variability among fifty four genotypes of forage maize including check variety African tall. Experiment was designed in randomized block design with two replications. In rabi 2018-19, each genotype was sown in two rows of $3 \mathrm{~m}$ length with $30 \mathrm{~cm}$ plant-to-plant distance and $60 \mathrm{~cm}$ inter row spacing.

Observations were recorded for 10 morphological characters, dry matter and crude protein content. Five randomly selected plants from each genotype were used to take observation except for days to 50 percent tasseling, 50 percent silking, dry matter and crude protein content, where observations were taken on the plot basis. 
Readings from five plants were averaged replication wise and the mean value was used for statistical analysis. Diversity analysis was done using Mahalanobis $\mathrm{D}^{2}$ statistics (1936) ${ }^{[12]}$. Fifty four genotypes were grouped into 7 clusters as per Tocher's method as described by Rao (1952) ${ }^{[17]}$. The intra and inter cluster $\mathrm{D}$ values were worked out using Mahalanobis $\mathrm{D}^{2}$ statistics.

\section{Results and Discussion}

The genetic divergence can be estimated by using an effective statistical tool, Mahalanobis $\mathrm{D}^{2}$ statistics, which gives clear idea about the diverse nature of the population. The analysis of variance carried out for all twelve quantitative traits among
54 genotypes was presented in Table 1. The mean sum of squares due to genotypes showed highly significant differences for all twelve traits under study at 5\% and $1 \%$ level of significance. Hence, presence of large amount of variability might be due to diverse source of materials taken for present study. This indicated that there is ample scope for selection of promising lines from the present gene pool for green forage yield and yield attributing traits. Significant differences among forage maize genotypes for forage yield and yield contributing traits were also reported by Roy (1953) ${ }^{[18]}$, More (2003) ${ }^{[14]}$, Nagaraju (2012) ${ }^{[15]}$, Kapoor and Batra (2015) ${ }^{[10]}$, Kapoor (2017) [9], Ahalawt et al. (2018) ${ }^{[1]}$, Rahim (2019) ${ }^{[16]}$ and Teron et al. (2020) ${ }^{[22]}$.

Table 1: Analysis of variance for 12 characters of fifty four maize genotypes

\begin{tabular}{|c|c|c|c|c|}
\hline Sr. No. & Character & Replication & Genotypes & Error \\
\hline & DF & 1 & 53 & 53 \\
\hline 1 & Days to 50\% tasseling & 0.330 & $84.770^{* *}$ & 1.710 \\
\hline 2 & Days to 50\% silking & 0.230 & $84.010^{* *}$ & 1.870 \\
\hline 3 & Plant height (cm) & 4.880 & $1623.930^{* *}$ & 66.220 \\
\hline 4 & No. of leaves/plant & 0.009 & $5.070^{* *}$ & 0.310 \\
\hline 5 & No. of internodes/plant & 1.040 & $5.790^{* *}$ & 0.440 \\
\hline 6 & Leaf length (cm) & 5.530 & $243.790^{* *}$ & 27.500 \\
\hline 7 & Leaf width (cm) & 0.300 & $2.280^{* *}$ & 0.220 \\
\hline 8 & Leaf::stem ratio & 0.001 & $0.006^{* *}$ & 0.002 \\
\hline 9 & Stem girth (cm) & 0.110 & $3.700^{* *}$ & 0.300 \\
\hline 10 & Dry matter content (\%) & 2.690 & $5.900^{* *}$ & 0.880 \\
\hline 11 & Crude protein content (\%) & 0.110 & $1.070^{* *}$ & 0.200 \\
\hline 12 & Green forage yield/plant (kg/plant) & 0.020 & $0.110^{* *}$ & 0.003 \\
\hline
\end{tabular}

The knowledge of genetic diversity among the genotypes is essential for selecting parents for hybridization programme, especially in a cross pollinated crop like maize. Fifty four genotypes were grouped into 7 clusters (Table 2.) as per Tocher's method as described by Rao (1952) ${ }^{[17]}$. Cluster I was the largest with 38 genotypes, followed by cluster VI with 7 genotypes, followed by cluster IV with 5 genotypes. Cluster II, III, V, and VII were monogenotypic. These four genotypes maintained separate identity and they were not included with any other cluster and exhibited high genetic diversity with most of the other clusters.
Distribution of genotypes in different clusters was random but it has clearly shown relationship with the characters for which they were bred. It indicated that genetic diversity and geographic diversity are not related. The pattern of group constellation proved the existence of significant amount of variability. Earlier workers Sonawane et al. (1991) ${ }^{[20]}$ and More (2003) ${ }^{[14]}$ grouped 45 forage maize genotypes into 7 clusters, Gautam (2008) ${ }^{[7]}$ grouped 135 genotypes into 15 clusters, Azad et al. (2012) ${ }^{[4]}$ grouped 30 genotypes into 6 clusters, Shukla et al. (2014) ${ }^{[19]}$ grouped 64 maize genotypes into 5 clusters and Ali et al. (2018) ${ }^{[3]} 30$ inbreds lines of maize into 4 clusters.

Table 2: Grouping of fifty four maize genotypes based on $\mathrm{D}^{2}$ analysis

\begin{tabular}{|c|c|c|}
\hline Cluster No. & Number of genotypes & Name of Genotypes \\
\hline & 38 & $52021,52045,52065,52068,52072,52081,52087,52093,52098,52113,52123,52141,52144,52169,52177,52$ \\
CL-I & 1 & $180,52184,52191,52212,52219,52222,52224,5227,52250,52255,52285,52310,52339,52346,52347,52349$ \\
& 1 & $, 52357,52373,52383,5243,52450,52485,52507,52623$ \\
\hline CL-II & 5 & 52217 \\
\hline CL-III & 1 & 52095 \\
\hline CL-IV & 7 & $52483,52623,52065,52332$, African tall \\
\hline CL-V & 1 & 52336 \\
\hline CL-VI & & $52014,52230,52237,52063,52018,52117,52200$ \\
\hline CL-VII & & 52506 \\
\hline
\end{tabular}

The intra and inter cluster D values were worked out using Mahalanobis $\mathrm{D}^{2}$ statistics. The mean $\mathrm{D}$ values (Table 3.) cluster elements were used as measures of intra and inter cluster distance. The maximum intra cluster distance was observed for cluster IV $(\mathrm{D}=7.71)$ followed by cluster I $(D=7.19)$, followed by cluster VI $(D=6.12)$ indicating that the genotypes of these clusters might be differing marginally in their genetic architecture. In the case of clusters II, III, V and VII the intra cluster distances are zero because of its monogenotypic nature.
The maximum inter cluster distance was observed between cluster IV and cluster VI $(\mathrm{D}=18.92)$ followed by cluster IV and cluster V $(\mathrm{D}=16.68)$, cluster III and cluster VI $(\mathrm{D}=16.33)$, cluster II and cluster VI ( $\mathrm{D}=14.74)$, cluster IV and cluster VII $(D=14.31)$ and cluster III and cluster V $(D=14.23)$. These results suggest maximum divergence between genotypes of these indicating the fact that the genotypes resent in one cluster differ entirely from those present in other clusters. While lowest divergence was noticed between cluster II and IV $(\mathrm{D}=7.77)$. 
Table 3: Average intra (bold) and inter cluster D values for seven clusters in fifty fourmaize genotypes

\begin{tabular}{|c|c|c|c|c|c|c|c|}
\hline Cluster & CL-I & CL-II & CL-III & CL-IV & CL-V & CL-VI & CL-VII \\
\hline CL-I & 7.19 & 9.13 & 10.25 & 12.80 & 9.18 & 10.55 & 12.21 \\
\hline CL-II & & 0.00 & 9.81 & 7.77 & 13.06 & 14.74 & 12.89 \\
\hline CL-III & & & 0.00 & 8.55 & 14.23 & 16.33 & 13.05 \\
\hline CL-IV & & & & 7.71 & 16.68 & 18.92 & 14.31 \\
\hline CL-V & & & & & 0.00 & 8.37 & 8.77 \\
\hline CL-VI & & & & & & 6.12 & 12.23 \\
\hline Cl-VII & & & & & & & 0.00 \\
\hline
\end{tabular}

The present study revealed that days to $50 \%$ tasseling contributed maximum (33.33\%) for divergence followed by L:S ratio $(20.27 \%)$, stem girth $(12.79 \%)$, leaf width $(7.34 \%)$, plant height $(6.08 \%)$ which contributed to $79.81 \%$ of total divergence. Minimum contribution towards the genetic divergence was to due green forage yield $(5.87 \%)$ followed by leaf length $(3.42 \%)$, No. of leaves $(2.87 \%)$, protein content (2.45), No. of internodes $(2.03 \%)$ and days to $50 \%$ silking
(0.35\%). This result was in accordance with Utkhede (1977) [23] and More (2003) ${ }^{[14]}$ reported high contribution to the divergence by days to 50 and tasseling, high contribution due plant height was reported by Caraballoso et al. (2002) ${ }^{[5]}$ and More (2003) ${ }^{[14]}$. High contribution to the divergence due to green forage yield was reported by Kumari and Shikha et al. (2018).

Table 4: Per cent contribution of 12 characters for divergence

\begin{tabular}{|c|c|c|c|}
\hline Sr. No. & Source & Times ranked first & Contribution \% \\
\hline 1 & Days to 50\% tasseling & 477 & 33.33. \\
\hline 2 & Days to 50\% silking & 5 & 0.35 \\
\hline 3 & Plant height (cm) & 87 & 6.08 \\
\hline 4 & No. of leaves/plant & 41 & 2.87 \\
\hline 5 & No. of internodes/plant & 29 & 2.03 \\
\hline 6 & Leaf length $(\mathrm{cm})$ & 49 & 3.42 \\
\hline 7 & Leaf width $(\mathrm{cm})$ & 105 & 7.34 \\
\hline 8 & Leaf::stem ratio & 290 & 20.27 \\
\hline 9 & Stem girth $(\mathrm{cm})$ & 183 & 12.79 \\
\hline 10 & Dry matter $(\%)$ & 46 & 3.21 \\
\hline 11 & Protein content $(\%)$ & 35 & 2.45 \\
\hline 12 & Green forage yield/plant $(\mathrm{kg})$ & 84 & 5.87 \\
\hline
\end{tabular}

A comparison of the mean value of twelve characters of different clusters is presented in the Table 5. Considerable differences in cluster mean values were evident for all the characters. On the basis of inter cluster distances, cluster mean and divergence class observed in the present study, the genotypes viz., 52095, 52217, 52336, 52483, 52507, 52623 and African Tall were distinct and diverse and could be classified as promising genotypes. These genotypes may be used in crossing programme to achieve desired segregants in forage maize.

Table 5: Mean values of the seven clusters for 12 characters in fifty four maize genotypes

\begin{tabular}{|c|c|c|c|c|c|c|c|c|c|c|c|c|}
\hline $\begin{array}{c}\text { Cluster } \\
\text { No. }\end{array}$ & $\begin{array}{c}\text { Days to } \\
\mathbf{5 0 \%} \\
\text { tasseling }\end{array}$ & $\begin{array}{c}\text { Days to } \\
\mathbf{5 0 \%} \\
\text { silking }\end{array}$ & $\begin{array}{c}\text { Plant } \\
\text { height } \\
\text { (cm) }\end{array}$ & $\begin{array}{c}\text { No. of } \\
\text { leaves/ } \\
\text { plant }\end{array}$ & $\begin{array}{c}\text { No. of } \\
\text { internodes/plant }\end{array}$ & $\begin{array}{c}\text { Leaf } \\
\text { length } \\
\text { (cm) }\end{array}$ & $\begin{array}{c}\text { Leaf } \\
\text { width } \\
(\mathbf{c m})\end{array}$ & $\begin{array}{c}\text { Leaf: } \\
\text { stem } \\
\text { ratio }\end{array}$ & $\begin{array}{c}\text { Stem } \\
\text { girth } \\
\text { (cm) }\end{array}$ & $\begin{array}{c}\text { Dry matter } \\
\text { content } \\
(\boldsymbol{\%})\end{array}$ & $\begin{array}{c}\text { Crude } \\
\text { protein } \\
\text { content }(\boldsymbol{\%})\end{array}$ & $\begin{array}{c}\text { Green forage } \\
\text { yield/plant } \\
(\mathbf{k g})\end{array}$ \\
\hline CL-I & 89.86 & 92.21 & 120.61 & 12.02 & 10.53 & 71.54 & 8.34 & 0.35 & 8.59 & 21.21 & 8.15 & 0.43 \\
\hline CL-II & 97.50 & 99.50 & 155.75 & 12.85 & 11.90 & 87.72 & 9.95 & 0.38 & 11.45 & 25.00 & 8.71 & 0.76 \\
\hline CL-III & 98.50 & 101.00 & 168.30 & 14.00 & 12.00 & 90.20 & 10.40 & 0.33 & 11.10 & 23.99 & 9.74 & 0.87 \\
\hline CL-IV & 98.50 & 100.80 & 178.08 & 14.66 & 13.18 & 93.35 & 9.96 & 0.28 & 10.79 & 24.13 & 8.81 & 1.01 \\
\hline CL-V & 80.50 & 83.00 & 131.95 & 10.65 & 7.20 & 66.85 & 7.30 & 0.31 & 7.35 & 20.31 & 7.90 & 0.31 \\
\hline CL-VI & 79.36 & 81.57 & 82.45 & 9.50 & 7.81 & 60.28 & 7.26 & 0.38 & 7.99 & 19.85 & 8.40 & 0.26 \\
\hline CL-VII & 80.00 & 83.00 & 178.50 & 12.10 & 10.15 & 92.10 & 9.45 & 0.35 & 9.35 & 21.95 & 9.17 & 0.92 \\
\hline
\end{tabular}

\section{Conclusion}

On the basis of inter cluster distances, cluster mean and divergence class observed in the present study, the genotypes 52095, 52217, 52336, 52483, 52507, 52623 and African Tall were distinct and diverse and could be classified as promising genotypes. These genotypes may be used in crossing programme to achieve desired segregants in forage maize.

\section{References}

1. Ahalawat NK, Arya VK, Pradeep K, Singh S. Genetic divergence in forage sorghum (Sorghum bicolor L. Moench). J App. Nat. Sci 2018;10(1):439-444.
2. Ahmed S, Malaviya AB, Majumdar AB. Genetic divergence and variability in fodder maize. Forage Res 2010;35:223-226.

3. Ali AH, Mohamed AM, Hasan Md AK, Azad, Hasanuzzaman Md. Genetic variability and diversity studies in maize (Zea mays L.) inbred lines. IOSR J Agric. Vet. Sci 2018;11(11):2319-2372.

4. Azad MAK, Biswas BK, Alam N, Alam SS. Genetic diversity in maize (Zea mays L.) inbred lines. The Agriculturists 2012;10(1):64-70.

5. Caraballoso-Torrecilla V, Mejia-Contreras A, Bolderrama-Castro S. Divergence in native maize 
populations in high valleys of Mexico. Agrociencia 2000;34(2):167-174.

6. Devi LG. Forage yield of maize (Zea mays L.) as influenced by nitrogen levels and biofertilizers. Forage Res 2002;27:263-266.

7. Gautam AS. Genetic divergence in maize. Int. J Agric. Sci 2008;4(2):466-472.

8. Gour V, Patel PC, Patel MR, Patel NN. Effect of sowing date and harvesting stage on forage yield and quality of maize. Forage Res 2006;31:267-268.

9. Kapoor R. Variability and character association studies in fodder maize (Zea mays L.) hybrids. Forage Res 2017;43(1):67-69.

10. Kapoor R, Batra C. Genetic variability and association studies in maize (Zea mays L.) for green fodder yield and quality traits. Elec. J Plant Breeding 2015;6(1):233.

11. Kumari S, Shahi JP, Mahato A, Singh S. Genetic divergence studies in maize hybrids based on morphological traits. J Pharm. Innov 2018;7(7):940-943.

12. Mahalanobis PC. On the generalised distance in statistics. Proc. Nat. Inst. Sci. India 1936;2:49-55.

13. Mahdi SS, Hasan B, Bhat RA, Aziz MA. Yield and economics of fodder maize as influenced by nitrogen and seed rate and zinc under temperate conditions. Forage Res 2010;36:22-25.

14. More A. Path analysis and genetic diversity for forage components in maize (Zea mays L.). Thesis submitted to the Mahatma Phule Krishi Vidyapeeth, Rahuri 2003.

15. Nagaraju K. Studies on genetic variability for yield and yield attributing characters in maize (Zea mays L). Thesis submitted to Acharya N.G. Ranga Agricultural University, Rajendranagar, Hyderabad 2012.

16. Rahim F, Khan MQ, Ashraf N, Shafi N, Khawaja S, Khalid S et al. Characterization of Zea mays L through morphological, biochemical and molecular markers. Appl. Ecol. Environ. Res 2019;17(3):6445-6456.

17. Rao CR. Advanced statistical methods in biometrical research. I John Willey and Sons, Inc. New York 1952, 390.

18. Roy NN. Studies on the Indian collection of maize varieties with special reference to the relationship between yield and other characters. Dissertation of associate ship of I.A.R.I., New Delhi 1953.

19. Shukla N, Jha A, Mishra DK, Singh S. Estimation of genetic diversity through $\mathrm{D}^{2}$ and group constellation methods in maize (Zea mays L.). Trends in Biosci 2014;7(9):781-785.

20. Sonowane MN, Patil FB. Genetic divergence in forage cowpea. J Maharashtra Agril. Univ 1991;16(2):161-169.

21. Takawale PS, Desale JS, Kauthale VK. Assessment of unpiloted maize (Zea mays L.) germplasm and its utilization in heterosis for forage traits. Indian $\mathrm{J}$ Genet 2009;69:159-161.

22. Teron R, Neog SB, Barua NS, Das K, Phukan SN. Evaluation of S1 line of maize (Zea mays L) for fodder related attributes. Int. J Agric. Sci 2020;12(7):9678-9682.

23. Utkhede RS. Multivariate analysis of genetic divergence in maize. East Afr. Agrilc. For. J 1977;42(4):414-419. 